\title{
Surveillance status and recent data for Mycoplasma pneumoniae infections in the European Union and European Economic Area, January 2012
}

A Lenglet (annick.lenglet@ecdc.europa.eu) ${ }^{1}$, Z Herrador $^{1}$, A P Magiorakos ${ }^{1}$, K Leitmeyer ${ }^{1}$, D Coulombier ${ }^{1}$, European Working Group on Mycoplasma pneumoniae surveillance ${ }^{2}$

1. European Centre for Disease Prevention and Control (ECDC), Stockholm, Sweden

2. Members of the group are listed at the end of the article

Lenglet A, Herrador Z, Magiorakos AP, Leitmeyer K, Coulombier D, European Working Group on Mycoplasma pneumoniae surveillance. Surveillance status and recent data for Mycoplasma pneumoniae infections in the European Union and European Economic Area, January 2012.

Euro Surveill. 2012;17(5):pii=20075. Available online: http://www.eurosurveillance.org/ViewArticle.aspx?Articleld=20075

Article published on 2 February 2012

In January 2012, the European Centre for Disease Prevention and Control (ECDC) conducted an emailbased survey of European Union and European Economic Area countries to describe the existing surveillance activities for Mycoplasma pneumoniae infections, recent findings and existence of clinical guidelines for the treatment of $M$. pneumoniae infection. Of the 20 countries that participated in the survey, seven reported increases in $M$. pneumoniae infections observed during the autumn and winter of 2011.

In the first week of January 2012, the Norwegian Medicines Agency reported a likely shortage of erythromycin in the country following an unusually high number of mycoplasma infections [1]. Additional epidemic intelligence activities conducted at the European Centre for Disease Prevention and Control (ECDC) highlighted that similar increases in $M$. pneumoniae infections had been observed during the autumn of 2011 in various northern European countries, including Sweden, Denmark, Finland and the Netherlands [2-6].

With this epidemiological background and because $M$. pneumoniae infection is not notifiable at the European Union (EU) level, ECDC, in collaboration with EU and European Economic Area (EEA) Member States, conducted a brief survey among countries in order to verify whether unusual increases in reporting rates were recently observed, to describe existing $M$. pneumoniae surveillance activities and availability of guidelines for the treatment atypical pneumoniae which might include $M$. pneumoniae infections for clinicians in the country.

An email-based questionnaire was sent to EU/EEA Member States contact points (listed as Competent Bodies for Threat Detection) on 10 January 2012. Countries were asked to provide answers by the evening of 12 January 2012.
The questions asked in the email questionnaire are shown in the Box.

\section{Disease background information}

Mycoplasma pneumoniae, a bacterium lacking a cell wall, is a major cause of respiratory disease in humans. Infection can lead to prolonged carriage and therefore serve as a reservoir for the spread of the pathogen to others [7]. It is transmitted from personto-person by respiratory droplets and its incubation period varies from one to three weeks, although it can be as short as four days [8]. M. pneumoniae infections tend to be endemic, punctuated by epidemics at fourto-seven-year intervals $[9,10]$. Climate, seasonality and geographical location are not thought to be of major importance, although in North America most epidemics usually begin during summer, peak in late autumn/

\section{Box}

Email questionnaire regarding Mycoplasma pneumoniae infection sent to EU/EEA countries, January 2012

1. Do you have MP surveillance ongoing in any form in your country?

2. If yes, please describe briefly which sources of information (including diagnostic tests, hospital-based/laboratory based, sentinel hospitals or standardised etc) are used by the ongoing surveillance in your country and whether there have been any major changes in the system in 2010 and 2011.

3. If you do have some form of MP surveillance, could you indicate whether you have seen any significant increases (or decreases) this autumn and winter or in previous years

4. Do you have existing national guidance for clinicians on the treatment atypical pneumonia, including infections with MP?

5. Do you have existing national guidance for handling outbreaks of atypical pneumonia, including with MP in institutional settings?

EEA: European Economic Area; EU: European Union; MP: Mycoplasma pneumoniae. 
early winter and fade out during winter $[8,11]$. However, this pattern seems to differ between continents $[8,11]$.

M. pneumoniae infects the upper and lower respiratory tracts in children and adults and is one of the aetiological agents of community-acquired pneumonia $[11,12]$. Studies have shown that it can cause up to $40 \%$ of community-acquired pneumonia and $18 \%$ of hospitalisations in children [13]. Most M. pneumoniae infections lead to overt clinical disease and although these infections are often self-limiting, $1-5 \%$ of cases may require hospitalisation. The most prominent symptoms are malaise, fever, headache and cough and in children aged less than five years, coryza and wheezing [13]. M. pneumoniae infection can also result in extrapulmonary manifestations, which can be present before, after or even in the absence of respiratory symptoms and have been reported with varying rates. Extrapulmonary manifestations of infection are rare, but when they occur can affect the central nervous system (including encephalitis and cranial nerve palsies) $[11,14]$ and can also result in dermatological, haematological and cardiac manifestations [13].

Diagnostic testing for $M$. pneumoniae includes, among others, polymerase chain reaction (PCR) and serological assays, each with varying sensitivities and specificities and limited standardisation between testing protocols $[15,16]$. PCR is the preferred method in some countries [17]; however, no testing method has proven reliable in the context of an outbreak [14]. Surveillance data for M. pneumoniae infections are likely to be underestimates because of the challenges in diagnosis as well as the fact that in many cases, the infection is often subclinical and usually dealt with in outpatient settings.

National and international guidelines are available for the management of community-acquired pneumonia, including for those caused by M. pneumoniae. Therapeutic decision-making is up to the clinical judgement of the treating physician based on clinical presentation, co-morbidities, risk factors, assessment of pneumonia severity and the available evidencebased guidelines. Effective antibacterial agents for the treatment of $M$. pneumoniae include macrolides, tetracyclines and fluoroquinolones. Prudent use of antibiotics is urged for all cases of $M$. pneumoniae infection because of worldwide reports of macrolide resistance. Moreover, it is suggested that treating clinicians be vigilant when prescribing macrolides for suspected or confirmed cases, particularly in areas with high rates of macrolide resistance, as treatment might fail in patients infected with macrolide-resistant isolates.

Recent studies on previous outbreaks in both community and institutional settings have been published from Denmark [9], England and Wales [18], Finland [19], France [20], Italy [21], the Netherlands [7] and Scotland [22].

\section{Survey findings}

Of the 30 countries contacted, 20 replied to the questionnaire (response rate: $67 \%$ ). Of those that replied, 13 reported having some type of surveillance activities providing data to monitor $M$. pneumoniae infections. Table 1 summarises the situation in 2011 and in previous seasons as well as surveillance activities. Seven countries had no available data that could be used to indicate changes in reporting rates for $M$. pneumoniae infections during 2011 compared with previous seasons. Of the 13 countries monitoring M. pneumoniae, seven indicated observing an increase compared with 2010 while six indicated no such increase (Belgium, Malta, Portugal, Slovakia, Slovenia and Spain). Of these six, Slovenia reported that reporting rates for M. pneumoniae infections were higher in the autumn of 2010 compared with the same period in 2011.

None of the responding countries reported major recent changes in the existing surveillance systems that would account for the observed increases. However, Sweden did highlight that awareness of $M$. pneumoniae among clinicians may be higher during this winter season, which may have resulted in more testing. Also, the widespread use of PCR for testing might have had an impact on current surveillance data.

With respect to which methods were used for laboratory diagnosis of $M$. pneumoniae, ten countries were able to provide some information. Five of these countries (the Netherlands, Norway, Spain, Sweden and the United Kingdom) reported using a mixture of serology and PCR. The Czech Republic and Portugal used mainly serological tests. Denmark and Slovenia reported data for samples confirmed by PCR and Finland reported using serology, PCR or culture for the diagnosis of M. pneumoniae.

A total of 15 countries reported some form of guidance available for clinicians for the treatment of atypical pneumonia, including M. pneumoniae infection; 10 countries have guidelines that are considered national (Table 2). Six reported the existence of guidelines that can be used in institutional outbreaks. Even though none are specific for $M$. pneumoniae infection, these guidelines would be applied in the occurrence of an outbreak of $M$. pneumoniae infection in institutional settings.

\section{Limitations of the study}

This survey was conducted as a part of epidemic intelligence activities conducted at the EU level. The questions included were not comprehensive enough to provide a complete and detailed overview of the functioning of the surveillance systems for M. pneumoniae infection in all countries. Details of diagnostic tests used, indicators for surveillance, frequency of surveillance, implicated stakeholders, etc. are therefore missing from this report. Furthermore, as clinical data and type of diagnostic test used for the diagnosis of each case were also not provided in the responses to 
the survey, we have not been able to provide a direct comparison of such data between countries in this report. Additionally, given the short deadline, it may have been difficult for several countries to collect the relevant information in time.

\section{Conclusion}

As expected, surveillance for $M$. pneumoniae infections across responding EU/EEA countries is highly variable in terms of data collected and methods of laboratory detection of cases. For this reason, comparisons of surveillance data from different countries have limitations. However, information from predominantly northern European countries (Denmark, Finland, the Netherlands, Norway, Sweden, United Kingdom) and the Czech Republic does suggest that the autumn of 2011 had an increase of $M$. pneumoniae infections reported through the existing surveillance systems. Data from Denmark as presented earlier and in this issue [9,23] and Sweden [24] suggests that the epidemic wave started in 2010. With the results from our study, however, we cannot assess whether the reported increases fit into the expected four- to-sevenyear epidemic waves even though this seems to be indicated by data from Finland, Norway and Denmark in this issue $[23,25,26]$.

Available data seem to suggest that Member States from southern Europe are not yet facing an increase as important as that reported in the northern countries. Increasing awareness among healthcare providers in countries not yet heavily affected could strengthen surveillance activities and ensure timely diagnosis and appropriate treatment of the disease in affected patients. It would be interesting to analyse whether in the countries where increases in $M$. pneumoniae infection rates were reported, similar increases or concurrent decreases in reporting rates for other respiratory pathogens took place during the same time period. However, this was beyond the scope of this assessment.

For the responding countries for which information was available, it is clear that all treating clinicians

TABLE 1

Availability of surveillance data for Mycoplasma pneumoniae infection and comparison with 2010, EU/EEA countries, January 2012

\begin{tabular}{|c|c|c|c|}
\hline Country & $\begin{array}{l}\text { Data available } \\
\text { on } M \text {. pneumoniae } \\
\text { infections }\end{array}$ & $\begin{array}{l}\text { Increase } \\
\text { compared } \\
\text { with } 2010\end{array}$ & Comments \\
\hline Czech Republic & Yes & Yes & $\begin{array}{l}\text { Numbers stable but percentage of positive samples } 35 \% \text { in } 2011 \text { compared with } 21 \% \\
\text { during the same period in } 2010 \text {. }\end{array}$ \\
\hline Denmark & Yes & Yes & $\begin{array}{l}\text { Almost twice as many samples were investigated in } 2011 \text { compared with } 2010 \text {, but the } \\
\text { proportion of } M \text {. pneumoniae-positive samples remained the same. } \\
\text { An epidemic was also seen in } 2010 \text { [9]. }\end{array}$ \\
\hline Finland & Yes & Yes & Increase in M. pneumoniae infections reported since October 2010. \\
\hline The Netherlands & Yes & Yes & $\begin{array}{l}\text { Important increase in M. pneumoniae infection reports in autumn 2011, similar to } \\
\text { previous epidemics in } 2002 \text { and } 2005 .\end{array}$ \\
\hline Norway & Yes & Yes & $\begin{array}{l}\text { Increase in } M . \text { pneumoniae-positive samples since September 2011. Last epidemic } \\
\text { reported in } 2005 / 06 \text { season. }\end{array}$ \\
\hline Portugal & Yes & No & $\begin{array}{l}\text { Retrospective data of discharged hospitalised cases, although underestimates, } \\
\text { suggests a mean of } 100 \text { cases of } M \text {. pneumoniae infection per year based on } \\
\text { laboratory results (serology), with no changes in the last } 10 \text { years. }\end{array}$ \\
\hline Sweden & Yes & Yes & All time high in M. pneumoniae infection reports during autumn 2011. \\
\hline United Kingdom ${ }^{a}$ & Yes & Yes & $\begin{array}{l}\text { Increase in } M . \text { pneumoniae infection reports since end of } 2011 \text {, in line with reports } \\
\text { during previous seasons. }\end{array}$ \\
\hline Belgium & Yes & No & No observed increase. \\
\hline Malta & Yes & No & No observed increase. \\
\hline Slovakia & Yes & No & No observed increase. \\
\hline Slovenia & Yes & No & Decrease compared with 2010. \\
\hline Spain & Yes & No & No observed increase. \\
\hline Cyprus & No & - & - \\
\hline France & No & - & - \\
\hline Greece & No & - & - \\
\hline Hungary & No & - & - \\
\hline Ireland & No & - & - \\
\hline Poland & No & - & - \\
\hline Romania & No & - & - \\
\hline
\end{tabular}

EEA: European Economic Area; EU: European Union.

a England, Wales and Scotland. 
TABLE 2

Existence and details of clinical guidelines available in EU/EEA countries for treatment of Mycoplasma pneumoniae infection, January 2012

\begin{tabular}{|c|c|c|}
\hline Country & Guidelines available & Details on available guidelines \\
\hline Belgium & Yes & $\begin{array}{l}\text { Case treatment: recommendations on treatment of lower respiratory infections from the Belgian } \\
\text { Antibiotic Policy Coordination Committee (BAPCOC) [http://www.bapcoc.be/]. }\end{array}$ \\
\hline Czech Republic & Yes & $\begin{array}{l}\text { Case treatment: (i) standards for the usage of antibiotics [http://www.cls.cz/dalsi-odborne- } \\
\text { projekty]; (ii) specific guidelines for diagnostics and treatment of pneumonia in adults [http:// } \\
\text { www.pneumologie.cz]. }\end{array}$ \\
\hline Denmark & Yes & $\begin{array}{l}\text { Case treatment: hospital-specific guidelines in addition to guidelines from Statens Serum Institut } \\
\text { [http://www.ssi.dk]. }\end{array}$ \\
\hline Finland & Yes & $\begin{array}{l}\text { Case treatment: national guidance for treatment of pneumonia, including } M . \text { pneumoniae infection } \\
\text { and other atypical pneumonia. }\end{array}$ \\
\hline France & Yes & $\begin{array}{l}\text { Case treatment: recommendations on treatment of lower respiratory infections from the } \\
\text { French Agency for the Safety of Health Products (Afssaps) [http://www.afssaps.fr/content/ } \\
\text { download/26334/348020/version/7/file/map-infections-respiratoires-basses-adultes.pdf]. } \\
\text { Institutional settings: national recommendations for treatment of lower respiratory infections in } \\
\text { homes for the elderly by the Ministry of Health [http://www.sante.gouv.fr]. }\end{array}$ \\
\hline Greece & Yes & $\begin{array}{l}\text { Case treatment: national treatment guidelines exist on the management of community-acquired } \\
\text { pneumonia, which include atypical pneumonia and infections with M. pneumoniae by the Hellenic } \\
\text { Centre for Disease Control and Prevention (KEELPNO) and the Hellenic Society of Infectious } \\
\text { Diseases [http://www.keelpno.gr]. } \\
\text { Institutional settings: KEELPNO has guidance for handling airborne infections in institutional } \\
\text { settings [http://www.keelpno.gr]. }\end{array}$ \\
\hline Hungary & Yes & $\begin{array}{l}\text { Case treatment: national guidance exists, but does not address the newer diagnostic methods } \\
\text { (e.g. PCR). }\end{array}$ \\
\hline Ireland & Yes & $\begin{array}{l}\text { Case treatment: Hospitals used their own guidelines for treatment of community-acquired } \\
\text { pneumonia based on the latest guidelines from the British Thoracic Society, European Respiratory } \\
\text { Society and the Infectious Disease Society of America. In children, the Paediatric Infectious } \\
\text { Disease Society guidelines for community-acquired pneumonia in children are usually followed. }\end{array}$ \\
\hline Malta & Yes & Case treatment: national guidelines have recently been published. \\
\hline $\begin{array}{l}\text { The } \\
\text { Netherlands }\end{array}$ & Yes & $\begin{array}{l}\text { Case treatment: (i) National Institute for Public Health and the Environment (RIVM): guideline } \\
\text { specific for M. pneumoniae infection; (ii) Dutch College of General Practitioners: guideline for } \\
\text { standard 'acute cough'. This includes case treatment of community-acquired pneumonia by } \\
\text { general practitioners; (iii) Dutch Working Party on Antibiotic Policy (SWAB): guideline on the } \\
\text { management of community-acquired pneumonia in adults } \\
\text { [http://www.swab.nl/swab/cms3.nsf/uploads/6929745C8C9BE541C125794900720B77/\$FILE/ } \\
\text { CAP_SWAB_Nov14-def.pdf]. } \\
\text { Institutional settings: guidelines for infectious respiratory disease outbreak management, but } \\
\text { not specific for M. pneumoniae.infection. }\end{array}$ \\
\hline Norway & Yes & Case treatment: National guidelines on which antibiotics to use. \\
\hline Portugal & Yes & $\begin{array}{l}\text { Case treatment: recommendations of the National Society of Pneumologists for treatment of } \\
\text { community-acquired pneumonia in hospitalised patients and outpatients covers infection with } \\
\text { atypical microorganisms in all types of patients [http://www.sppneumologia.pt] }\end{array}$ \\
\hline Romania & Yes & $\begin{array}{l}\text { Case treatment: each infectious diseases clinic receives guidelines prepared by specialists from } \\
\text { the Regional Academic Centre. }\end{array}$ \\
\hline Slovakia & Yes & $\begin{array}{l}\text { Case treatment: guidance on the management of } M \text {. pneumoniae infection is included in guidance } \\
\text { of management atypical pneumonia, which has been prepared by a working group of experts from } \\
\text { the Slovakian Pneumological Society. }\end{array}$ \\
\hline Slovenia & Yes & $\begin{array}{l}\text { Case treatment: national treatment guidelines exist [http://www.szd.si/user_files/vsebina/ } \\
\text { Zdravniski_Vestnik/2010/marec/245-64.pdf]. }\end{array}$ \\
\hline Spain & Yes & $\begin{array}{l}\text { Case treatment: several national guidance documents for clinicians on treatment the atypical } \\
\text { pneumonia prepared by scientific societies such as the Spanish Society of Infectious Diseases } \\
\text { and Clinical Microbiology and Spanish Association of Paediatric Primary Care. } \\
\text { Institutional settings: infection control guidance for institutional care settings and nosocomial } \\
\text { outbreaks, including respiratory tract infections. }\end{array}$ \\
\hline Sweden & Yes & $\begin{array}{l}\text { Case treatment: STRAMA (Swedish strategic programme against antibiotic resistance) guidance } \\
\text { on how to treat pneumonia in outpatient care. }\end{array}$ \\
\hline United Kingdom & Yes & $\begin{array}{l}\text { Case treatment: guidance on the management of community-acquired pneumonia by the British } \\
\text { Thoracic Society, which includes consideration and treatment of, M. pneumoniae infection } \\
\text { [http://www.brit-thoracic.org.uk/Portals/o/Clinical\%2olnformation/Pneumonia/Guidelines/ } \\
\text { CAPGuideline-full.pdf]. } \\
\text { Institutional settings: the Health Protection agency has guidance on the management of } \\
\text { outbreaks of acute respiratory infection in institutional settings. }\end{array}$ \\
\hline Cyprus & Data not available & - \\
\hline Poland & Data not available & - \\
\hline
\end{tabular}


have access to guidance on how to treat $M$. pneumoniae infections even though it is a reality that the majority of these infections remain undetected and under-diagnosed.

European Working Group on Mycoplasma pneumoniae surveillance

ECDC: Edit Szegedi, Jas Mantero, Marc Struelens, Eeva Broberg, Pasi Penttinen, Dominique L. Monnet; Belgium: Françoise Wuillaume (Scientific Institute of Public Health, Belgium), Geneviève Ducoffre (Scientific Institute of Public Health, Belgium); Cyprus: Avgi Hadjiloukas (Ministry of Health), Chrystalla Hadjianastasiou (Directorate of Medical and Public Health Services); Czech Republic: Martina Havlickova (National Institute of Public Health) and Jan Kyncl (National Institute of Public Health); Denmark: Søren Uldum (Statens Serum Institut); Finland: Markku Kuusi (National Institute for Health and Welfare); France: Department for Infectious Diseases and Department for Alert Coordination and Regional Offices (Institut de Veille Sanitaire); Greece: Helena Maltezou, Flora Kontopidou, Theano Georgakopoulou (Hellenic Centre for Disease Control and Prevention); Hungary: Eszter Balla (National Centre for Epidemiology, Department of Bacteriology); Ireland: Jeff Connell (National Virus Reference Laboratory, University College Dublin), Karen Burns (Health Protection Surveillance Centre, Dublin), Robert Cunney (Health Protection Surveillance Centre, Dublin); Malta: Tanya Melillo Fenech and Paul Caruana (Ministry of Health, the Elderly and Community Care); the Netherlands: Dutch working group on clinical virology and Centre for Infectious Disease Control, Institute for Public Health and the Environment; Norway: Hans Blystad and Gabriel Ånestad (Norwegian Institute of Public Health); Poland: Matgorzata Wojdowska (Chief Sanitary Inspectorate); Portugal: Filipe Froes (Hospital Pulido Valente and General Directorate of Health Consultant for Pneumology); Romania: Anca Sirbu (National Institute of Public Health); Slovakia: Mária Avdičová (Regional Public Health Authority); Slovenia: Darja Kese (Institute of Microbiology and Immunology, University of Ljubljana) and Maja Socan (National Institute of Public Health); Spain: Rosa Cano Portero (National Center for Epidemiology, Instituto Carlos de Salud Publica III), Sara Santos Sanz and Berta Suárez Rodríguez (Coordination for Alerts and Public Health Emergencies, Directorate General of Public Health, Ministry of Health, Social Affairs and Equality; Sweden: Anders Ternhag and Annika Linde (Smittskyddsinstitutet); United Kingdom: Arlene Reynolds, Jim McMenamin and Beatrix von Wissmann (Health Protection Scotland) and Tim Harrison and Vicki Chalker (Health Protection Agency, Colindale).

\section{References}

1. Norwegian Institute of Public Health. Mycoplasma pneumoniae-infeksjoner - mangel på erytromycin. [Mycoplasma pneumoniae infections - shortage of erythromycin]. Oslo: Norwegian Institute of Public Health; 2012. Updated 4 Jan 2012. [Accessed 12 Jan 2012]. Norwegian. Available from: http://www.fhi.no/eway/default.aspx?pid=233 \&trg=MainLeft_5588\&MainArea_5661=5588:94827:15,1787:1: 0:0:::0:0\&MainLeft_5588=5544:94827::1:5569:2:::0:0

2. National Institute for Public Health and the Environment (RIVM). Meldingen uit de virologische laboratoria tot en met week 44 2011. [Reports from the virological laboratories through week 44 in 2011]. Bilthoven: RIVM; 2011. Updated 21 Dec 2011. [Accessed 12 Jan 2012]. Dutch. Available from: http://www.rivm.nl/Bibliotheek/Algemeen_Actueel/Uitgaven/ Infectieziekten_Bulletin/Jaargang_22/December_2011/ Inhoud_december_2011/Meldingen_uit_de_virologische laboratoria_tot_en_met_week_44_2011

3. Smittskyddsinstitutet. Mycoplasma aktuellt - igen. 2012 [Mycoplasma update - again]. Updated 11 Mar 2011. Solna: Smittskyddsinstitutet; 2012. [Accessed 12 Jan 2012]. Swedish.
Available from: http://www.smittskyddsinstitutet.se/ nyhetsarkiv/2011/mycoplasma-aktuellt--igen/

4. National Institute for Health and Welfare (THL). Mykoplasmaa edelleen liikkeellä (05.12.2011). [Mycoplasma are still in circulation (05.12.2011)]. Helsinki: THL; 2011. [Accessed 12 Jan 2012]. Finnish. Available from: http://www.ktl.fi/portal/ suomi/osastot/infe/tutkimus/tartuntatautien_seuranta/ tartuntatautilaakarin_kommentit

5. Norwegian Institute of Public Health. Økt forekomst av Mycoplasma pneumoniae-infeksjoner. [Increased prevalence of Mycoplasma pneumoniae infections]. Oslo: Norwegian Institute of Public Health; 2011. Updated 28 Oct 2011. [Accesssed 12 Jan 2012]. Norwegian. Available from: http://www.fhi.no/eway/ default.aspx?Area_5774=5544:92470::1:5776:1:::0:0\&MainAre a_5661=5588:0:15,1787:1:0:0:::0:0\&MainLeft_5588=5774:0:15 ,1787:1:0:0:::0:0\&pid=233\&trg=Area_5774

6. Statens Serum Institut (SSI). Stigning i Mycoplasma pneumoniae-tilfælde. [Increase in Mycoplasma pneumoniae infections]. Copenhagen: SSI; 2011. Updated 12 Oct 2011. [Accessed 12 Jan 2012]. Danish. Available from: http://www. ssi.dk/Aktuelt/Nyheder/2011/2011_stigning_i_mycoplasma pneumoniae_121011.aspx

7. Dorigo-Zetsma JW, de Wit M, Szabó JS, Schneeberger PM. [Epidemic of respiratory tract infections by Mycoplasma pneumoniae in an institute for mentally disabled, investigated with polymerase chain reaction of a throat swab specimen]. Ned Tijdschr Geneeskd. 1999;143(24):1261-5. Dutch.

8. Sánchez-Vargas FM, Gómez-Duarte OG. Mycoplasma pneumoniae-an emerging extra-pulmonary pathogen. Clin Microbiol Infect. 2008;14(2):105-17.

9. Rasmussen JN, Voldstedlund M, Andersen RL, EllermannEriksen S, Jensen TG, Johansen HK, et al. Increased incidence of Mycoplasma pneumoniae infections detected by laboratory-based surveillance in Denmark in 2010. Euro Surveill. 2010;15(45): pii=19708. Available from: http://www. eurosurveillance.org/ViewArticle.aspx?Articleld=19708

10. Rastawicki W, Kaluzewski S, Jagielski M, Gierczyski R. Epidemiology of Mycoplasma pneumoniae infections in Poland : 28 years of surveillance in Warsaw 1970-1997. Euro Surveill. 1998;3(10):pii=95. Available from: http://www. eurosurveillance.org/ViewArticle.aspx?Articleld =95

11. Atkinson TP, Balish MF, Waites KB. Epidemiology, clinical manifestations, pathogenesis and laboratory detection of Mycoplasma pneumoniae infections. FEMS Microbiol Rev. 2008;32(6):956-73.

12. Nijs J, Nicolson GL, De Becker P, Coomans D, De Meirleir K. High prevalence of Mycoplasma infections among European chronic fatigue syndrome patients. Examination of four Mycoplasma species in blood of chronic fatigue syndrome patients. FEMS Immunol Med Microbiol. 2002 15;34(3):209-14.

13. Waites KB, Talkington DF. Mycoplasma pneumoniae and its role as a human pathogen. Clin Microbiol Rev. 2004;17(4):697-728.

14. Thurman KA, Walter ND, Schwartz SB, Mitchell SL, Dillon MT, Baughman AL, et al. Comparison of laboratory diagnostic procedures for detection of Mycoplasma pneumoniae in community outbreaks. Clin Infect Dis. 2009;48(9):1244-9.

15. Hammerschlag MR. Mycoplasma pneumoniae infections. Curr Opin Infect Dis. 2001;14(2):181-6.

16. von Baum H, Welte T, Marre R, Suttorp N, Lück C, Ewig S. Mycoplasma pneumoniae pneumonia revisited within the German Competence Network for Community-acquired pneumonia (CAPNETZ). BMC Infect Dis. 2009;9:62.

17. Claesson BE, Enroth H, Elowson S, Hellgren-Leonardsson M, Skövde S. Evaluation of diagnostic methods for Mycoplasma pneumoniae and Chlamydia pneumoniae using serology, PCR and the BD ProbeTec ET System. Clin Microbiol Infect. 2004;10, Supplement 3;6. Available from: http://www. blackwellpublishing.com/eccmid14/clm_902_0.pdf

18. Chalker VJ, Stocki T, Mentasti M, Fleming D, Sadler C, Ellis , et al. Mycoplasma pneumoniae infection in primary care investigated by real-time PCR in England and Wales. Eur J Clin Microbiol Infect Dis. 2011;30(7):915-21.

19. Kleemola M, Jokinen C. Outbreak of Mycoplasma pneumoniae infection among hospital personnel studied by a nucleic acid hybridization test. J Hosp Infect. 1992;21(3):213-21.

20. Dekeyser S, Bonnel C, Martinet A, Descamps D. [Usefulness of PCR test for the management of a Mycoplasma pneumoniae outbreak in Bethune Hospital (Pas-de-Calais, France)]. Pathol Biol (Paris). 2011;59(2):83-7. French.

21. Chironna M, Sallustio A, Esposito S, Perulli M, Chinellato I, Di Bari C, et al. Emergence of macrolide-resistant strains during an outbreak of Mycoplasma pneumoniae infections in children. J Antimicrob Chemother. 2011;66(4):734-7. 
22. Ghosh K, Clements GB. Surveillance of Mycoplasma pneumoniae infections in Scotland 1986-1991. J Infect. 1992;25(2):221-7.

23. Uldum SA, Bangsborg JM, Gahrn-Hansen B, Ljung R, Mølvadgaard M, Føns Petersen R, Wiid Svarrer C. Epidemic of Mycoplasma pneumoniae infection in Denmark, 2010 and 2011. Euro Surveill. 2012;17(5):pii=20073. Available from: http:// www.eurosurveillance.org/ViewArticle.aspx?Articleld $=20073$

24. Linde A, Brytting M. En ökning av antalet mycoplasmainfektioner i Sverige. [An increase in the number of Mycoplasma infections in Sweden]. Solna: Smittskyddsinstitutet; 2010. [Accessed 27 Jan 2012]. Swedish. Available from: http://www.smittskyddsinstitutet.se/ publikationer/smis-nyhetsbrev/epi-aktuellt/epi-aktuellt-2010/ epi-aktuellt-vol-9-nr-49-9-december-2010-/\#p18642

25. Polkowska A, Harjunpää A, Toikkanen S, Lappalainen $M$ Vuento R, Vuorinen T, Kauppinen J, Flinck H, Lyytikäinen 0. Increased incidence of Mycoplasma pneumoniae infection in Finland, 2010-2011. Euro Surveill, 2012;17(5): pii=20072. Available from: http://www.eurosurveillance.org/ViewArticle. aspx?Articleld $=\mathbf{2 0 0 7 2}$

26. Blystad H, Ånestad G, Vestrheim DF, Madsen S, Rønning K. Increased incidence of Mycoplasma pneumoniae infection in Norway 2011. Euro Surveill. 2012;17(5):pii=20074. Available online: http://www.eurosurveillance.org/ViewArticle.

aspx?Articleld $=20074$ 